\title{
Where did the rats of Big South Cape Island come from?
}

\author{
Judith H. Robins ${ }^{1,2, *}$, Steven D. Miller ${ }^{3}$, James C. Russell ${ }^{1,4}$, Grant A. Harper ${ }^{5}$, Rachel M. Fewster ${ }^{4}$ \\ ${ }^{1}$ School of Biological Sciences, University of Auckland, Private Bag 92019, Auckland 1142, New Zealand \\ ${ }^{2}$ Department of Anthropology, University of Auckland, Private Bag 92019, Auckland 1142, New Zealand \\ ${ }^{3}$ Department of Statistics, University of Waikato, Private Bag 3105, Hamilton 3240, New Zealand \\ ${ }^{4}$ Department of Statistics, University of Auckland, Private Bag 92019, Auckland 1142, New Zealand \\ ${ }^{5}$ Biodiversity Restoration Specialists Ltd, PO Box 58, St Arnaud 7053, New Zealand \\ * Author for correspondence (Email: j.robins@auckland.ac.nz)
}

Published online: 12 January 2016

\begin{abstract}
The ship rat invasion of Big South Cape Island/Taukihepa in the 1960s was an ecological catastrophe that marked a turning point for the management of rodents on offshore islands of New Zealand. Despite the importance of this event in the conservation history of New Zealand, and subsequent major advances in rodent eradication and biosecurity, the source and pathway of the rat invasion of Big South Cape Island has never been identified. Using modern molecular methods on contemporary and historical tissue samples, we identify the mitochondrial DNA (mtDNA) haplotype of ship rats (Rattus rattus) on Big South Cape Island and compare it to that of ship rats in the neighbouring regions of Stewart Island/Rakiura and southern New Zealand, all hypothesised as possible source sites for the invasion. We identify two haplotype clusters, each comprising three closely related haplotypes; one cluster unique to Stewart Island, and the other found in southern New Zealand and elsewhere. By a process of elimination we rule that the ship rat invasion of Big South Cape Island was neither by swimming nor boat transport from Stewart Island, and is unlikely to have come from the south coast ports of New Zealand. However, because the ship rat haplotype found on Big South Cape Island is cosmopolitan to New Zealand's South Island and elsewhere, we can only confirm that the invasion likely originated from some distance, but are not able to identify the invasion source more precisely. An unexpected consequence of our study is the discovery of five new mtDNA haplotypes for $R$. rattus that have not been previously reported.
\end{abstract}

Keywords: mtDNA, haplotypes, Stewart Island, genetics, Big South Cape Island, rodent invasion, ship rat, Rattus rattus

\section{Introduction}

European sailing ships carried rats throughout the world (Atkinson 1985). Norway rats (Rattus norvegicus) likely arrived in New Zealand by 1800 , and ship rats (R. rattus) by the middle of the 19th century. By about 1860 both species had become widespread in New Zealand (Atkinson 1973).

Big South Cape Island/Taukihepa is a small island (1040 ha, $\left.47^{\circ} 14^{\prime} \mathrm{S}, 169^{\circ} 25^{\prime} \mathrm{E}\right)$ and at its closest point it lies roughly 1.5 kilometres off the south western corner of Stewart Island/ Rakiura, New Zealand (Figure 1). The island is visited seasonally by small groups of people collecting mutton birds and was rat-free until the 1960s (Bell 1978). By 1964 however, ship rats $(R$. rattus) were well established throughout the island, and damage to the mutton-birders' cabins, bedding and stored food supplies was evident (Bell et al. 2016). There was subsequently a marked decline in birdlife, invertebrates, and some plants including both local and global extinctions (Bell 1978).

A single ship rat had been trapped on Big South Cape Island years earlier in 1955, but no other evidence of rats was found until the invasion in 1963 (Bell 1978). In hindsight this probably represented an independent incursion of a single rat on to the island (Russell \& Clout 2005). Prevailing knowledge at the time of the invasion also suggested that the introduction must have been a human-assisted dispersal. Fishing boats working in the area, possibly even those that transported the mutton-birders, were generally suspected as the source of the rats (Bell et al. 2016), although where the rats might have boarded such boats was an open question. Once again in hindsight, at only 1.5 kilometres offshore, Big South Cape Island is within the known swimming range of Norway rats (Russell \& Clout 2005), and while it is outside the known swimming range of ship rats (e.g. Russell et al. 2010), invasion by swimming cannot be entirely ruled out at this distance. Rats were first detected around areas of human occupation at the northern end of the island, which lends further support to the invasion having been human-mediated. Initial detections of rat incursions, however, are inevitably linked to areas of human habitation and monitoring through observer bias (Russell et al. 2010), and the northern end of Big South Cape Island is also that closest to adjacent Stewart Island. Together these facts meant that neither the source nor the pathway of the original invasion of Big South Cape Island could be readily ascertained at the time.

The invasion of Big South Cape Island by ship rats also marked a changing point in the culture and management towards introduced rats in New Zealand (Bell et al. 2016). The impact of rats on the island was clear and led managers to understand the urgency with which rats should be eradicated from other islands (Moors 1985; Taylor \& Thomas 1993). Rats were finally eradicated from Big South Cape Island itself in 2006 (McClelland et al. 2011).

Since the invasion of Big South Cape Island new technologies have been developed which allow rodent managers to determine the source and rates of invasions (e.g. Abdelkrim et al. 2005; Bagasra et al. 2016). Advances in wildlife forensics employing molecular tools such as DNA 


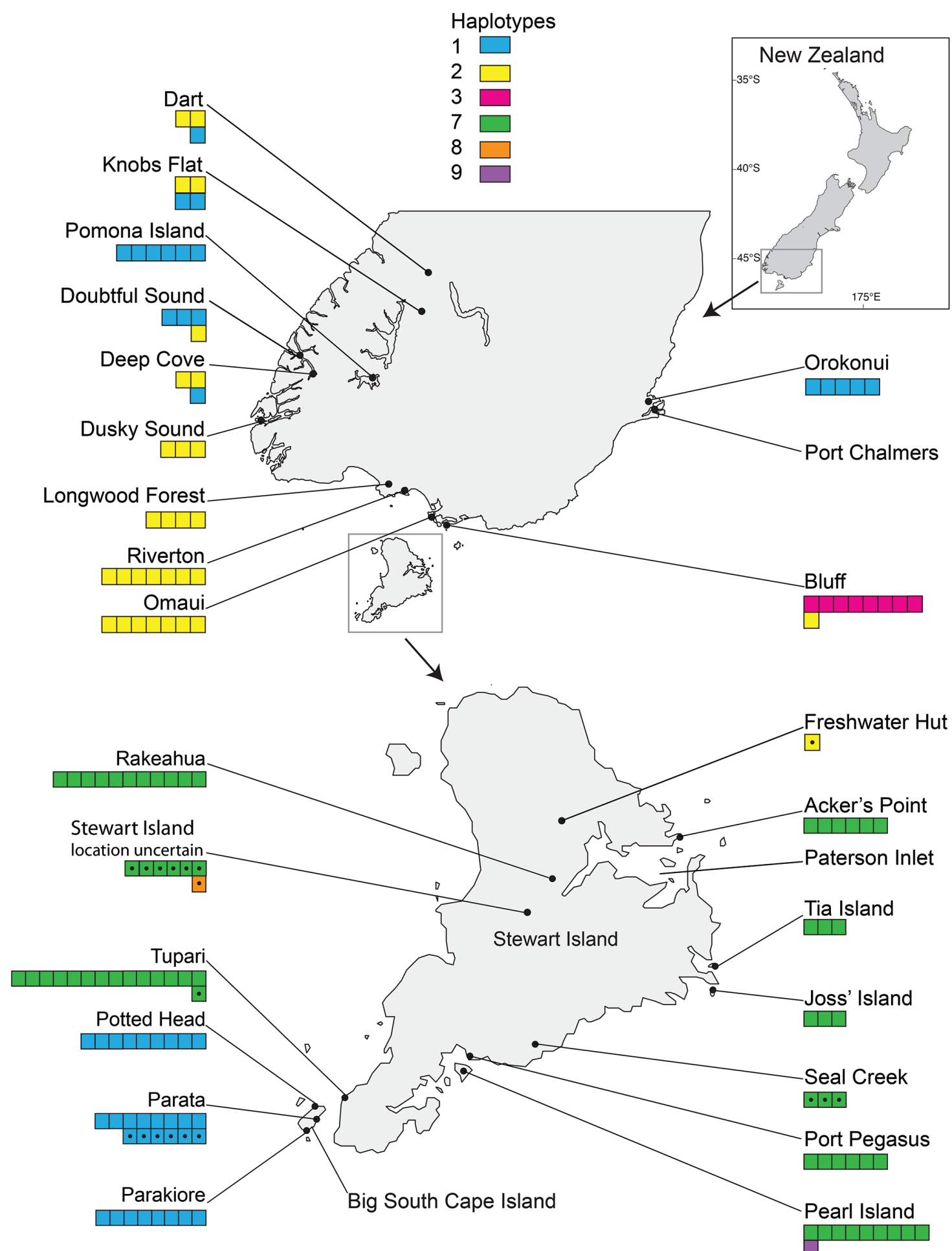

Figure 1. Map of New Zealand, showing the locality, the number and the haplotypes of samples used in this study. The samples are indicated by boxes: one box $=$ one sample, and a box with a central dot indicates an historic sample collected just after the invasion in the $1960 \mathrm{~s}$.

profiling using microsatellite markers have enabled scientists to determine the source of rat invasions (Fewster et al. 2011), and meta-population units for rat eradication (Robertson \& Gemmell 2004). In a proximate location to Big South Cape Island, rats were captured on Pearl Island, off south-east Stewart Island (Figure 1) in 2006, nine months after an eradication attempt in 2005. At the time it was not known whether the newly-captured rats were re-invaders from neighbouring
Stewart Island, or survivors of the eradication attempt. Russell et al. (2010) demonstrated the application of molecular tools to verify that in this case, the source of the new population was re-invaders across the 225 metre dividing channel.

In this paper we apply molecular tools in an attempt to determine the most likely source and pathway for the 1960 s rat invasion of Big South Cape Island. The island was continually inhabited by ship rats from the time of the 1964 irruption to 
the eradication in 2006 (Bell et al. 2016; Harper \& Rutherford 2016). Our analysis is possible due to the availability of rat samples from the island which are both contemporary (just prior to the eradication; Harper \& Rutherford 2016) and historical (just after the invasion; Te Papa Museum specimens). Analysis of the hypervariable region of mitochondrial DNA, known as the D-loop, allows a broad-scale assessment of population differences, and matches recent approaches used in studies of the ship rats of Madagascar (Hingston et al. 2005; Tollenaere et al. 2010). By comparing the D-loop signature of rats from Big South Cape Island with that of rats from surrounding locations, which have previously been hypothesised as potential sources for the invasion (Table 1), we attempt to resolve the question, "where did the rats on Big South Cape Island come from?"

Table 1. Hypothesised sources and pathways of the 1960s rat invasion of Big South Cape Island.

\begin{tabular}{|c|c|c|}
\hline Source & Pathway & Description \\
\hline Tupari, SW Stewart Island & Swimming & $\begin{array}{l}\text { Adjacent } \\
\text { island }\end{array}$ \\
\hline $\begin{array}{l}\text { Port Pegasus, SE Stewart } \\
\text { Island }\end{array}$ & Boat & Boat anchorage \\
\hline $\begin{array}{l}\text { Paterson Inlet, NE Stewart } \\
\text { Island }\end{array}$ & Boat & $\begin{array}{l}\text { Boat anchorage } \\
\& \text { fishing port }\end{array}$ \\
\hline Bluff, Southland & Boat & $\begin{array}{l}\text { Major fishing } \\
\text { port }\end{array}$ \\
\hline Doubtful Sound, SW Fiordland & Boat & $\begin{array}{l}\text { Boatanchorage } \\
\text { (particularly } \\
\text { fishing) }\end{array}$ \\
\hline Port Chalmers, Otago & Boat & $\begin{array}{l}\text { Major port and } \\
\text { town }\end{array}$ \\
\hline
\end{tabular}

\section{Methods}

\section{Samples}

We analysed a total of 152 ship rat tissue samples from the southern part of New Zealand, including 31 from Big South Cape Island and 66 from Stewart Island (Figure 1). Seventeen were historic samples collected in the 1960s, from Big South Cape Island $(n=6)$ and Stewart Island $(n=11)$, shortly after the Big South Cape Island rat invasion. The historic samples were obtained from Te Papa Museum in Wellington, New Zealand, and the remaining 135 tissue samples were collected from 2005 to 2014 . The tissues were preserved in $70 \%$ ethanol and were either tail snips or feet.

\section{DNA extraction and amplification}

DNA was extracted using the DNeasy Tissue Kit (Qiagen) or the High Pure PCR Template Preparation Kit (Roche Diagnostics). The $585 \mathrm{bp}$ amplicon of the D-Loop was amplified with the primers EGL4L and RJ3R (Robins et al. 2007). The reaction volume was $20 \mu \mathrm{L}$ comprising: $10 \mathrm{mM}$ Tris $\mathrm{HCl} \mathrm{pH} \mathrm{8.3;} 50 \mathrm{mM} \mathrm{KCl}, 2.5 \mathrm{mM} \mathrm{MgCl}_{2}$, primers at 0.5 $\mu \mathrm{M}$ each, dNTPs at $0.15 \mathrm{mM}$ each; $0.5 \mathrm{U}$ of Taq polymerase, $1 \mu \mathrm{L}$ of DNA template. The PCR (polymerase chain reaction) regime was an initial denaturation step of $94^{\circ} \mathrm{C}$ for $2 \mathrm{~min} ; 35$ cycles of $94^{\circ} \mathrm{C}$ for $30 \mathrm{~s}, 60^{\circ} \mathrm{C}$ for $30 \mathrm{~s}$ and $72^{\circ} \mathrm{C}$ for $1 \mathrm{~min}$ with a final extension step of $72^{\circ} \mathrm{C}$ for $5 \mathrm{~min}$. PCR products were visualised and quantified, using a low mass ladder for comparison, on ethidium bromide stained 1\% agarose gels. PCR products were purified with ExoSAP-IT (Affymetrix, Inc.). Sequencing was carried out at the Massey University Genome Service, Palmerston North, New Zealand, using the BigDye Terminator version 3 sequencing kit, the GeneAmp PCR System 9700 and a capillary ABI3730 DNA analyser, all from Applied Biosystems.

The raw sequences were trimmed, edited, aligned and grouped into haplotypes using the software package SEQUENCHER (Gene Codes). The relationships among the haplotypes were estimated with a minimum spanning haplotype network (Bandelt et al. 1999) as implemented in PopART (http://popart.otago.ac.nz).

\section{Results}

The aligned sequences, 546 nucleotides long, had differences in the base composition at six positions, and six haplotypes were found (Table 2). The relationships among the haplotypes are shown in Figure 2. The haplotype frequencies together with the geographic origins of the samples are summarised in Figure 1 and Table 3.

Haplotype 1 has a world-wide distribution, including Antilles, Britain, Europe, French Polynesia, Guadeloupe, Mediterranean Basin, New Guinea, New Zealand, Polynesia, West Africa, and the USA (Robins et al. 2007; Nilsson et al. 2010; Tollenaere et al. 2010; Colangelo et al. 2015). It is common in New Zealand, but we did not find it on Stewart Island. The other five haplotypes have not been reported previously on GenBank or in the literature. Haplotype 2 is widespread in New Zealand, and we found a single specimen on Stewart Island. Haplotype 3 is unique to the Bluff region of the South Island; and haplotype 7, although widespread on Stewart Island, is unique to it. Haplotypes 8 and 9 each have single-nucleotide variations from haplotype 7 , and are each represented by single samples that occurred on Stewart Island and Pearl Island respectively.

The Big South Cape Island samples are all of haplotype 1, which differs by two bases from the common Stewart Island haplotype. This difference in haplotype between the islands is consistent in both the historic and the recent samples. No intermediate form, i.e. a haplotype showing only one of the two base differences, has been found thus far.

Table 2. Variable nucleotides compared with haplotype 1. This haplotype is the same as that of the GenBank mitochondrial reference genome for $R$. rattus (accession number NC_012374) and the position numbers are from this reference genome. Nucleotides represented by "." are the same as those in haplotype 1.

\begin{tabular}{ccccccc}
\hline Haplotype \# & \multicolumn{6}{c}{ Positions where nucleotides vary } \\
& 15513 & 15543 & 15653 & 15757 & 15760 & 15822 \\
\hline 1 & C & C & C & C & A & T \\
2 &. &. &. & T &. &. \\
3 & T &. &. &. &. &. \\
7 &. & T &. &. & G &. \\
8 &. & T & T &. & G &. \\
9 &. & T &. &. & G & C \\
\hline
\end{tabular}


Table 3. The number of samples of each haplotype, the GenBank accession number and the geographical regions where these haplotypes are found. South Island regions are defined as: Fiordland (includes Doubtful Sound, Deep Cove, Dusky Sound, Pomona Island, Knobbs Flat, Dart/Routeburn); Port Chalmers (includes Orokonui); and South Coast (includes Longwood Forest, Riverton, Omaui, Bluff).

\begin{tabular}{ccll}
\hline Haplotype \# & $\mathbf{n}$ & Location & GenBank Accession \# \\
\hline 1 & 49 & Big South Cape Is, Fiordland, Port Chalmers. & KR559034 \\
2 & 30 & South Coast, Fiordland; one historic sample on Stewart Is. & KR559035 \\
3 & 8 & Bluff. & KR559036 \\
7 & 63 & Stewart Is and surrounding islands (Joss Is, Tia Is, Pearl Is). & KR559037 \\
8 & 1 & Stewart Is. & KR559038 \\
9 & 1 & Pearl Is. & KR559039 \\
\hline
\end{tabular}

\section{Haplotypes $1 \bigcirc \mathrm{n}=44$ $2 \bigcirc \mathrm{n}=31$ $3 \bigcirc \mathrm{n}=8$ $7 \bigcirc n=63$ $8 \bigcirc n=1$ $9 \bigcirc n=1$}

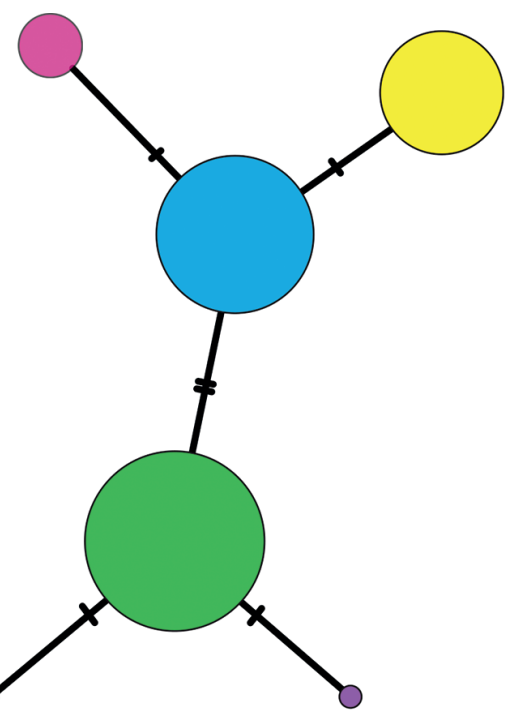

Figure 2. Relationships among the six haplotypes sampled in our study. Each circle represents a haplotype, the sizes of the circles are proportional to the number of samples, and each bar represents a single nucleotide change. For example haplotype 1 differs from haplotype 2 by one base and from haplotype 7 by two bases.

\section{Discussion}

We found moderate levels of diversity and spatial segregation in D-loop mtDNA haplotypes of ship rats of southern New Zealand. Similar levels of haplotype diversity have been found in ship rats of northern New Zealand (Miller 2008) and elsewhere in the world including islands such as Madagascar (Hingston et al. 2005; Tollenaere et al. 2010) and the Canary Islands (López et al. 2013). Moderate haplotype diversity was also found in the Mediterranean Basin (Colangelo et al. 2015). It is noteworthy, however, that five of our six haplotypes have not been reported in earlier studies. Where present, these levels of diversity allow researchers to assign the origin of ship rat populations in some circumstances (e.g. Russell et al. 2011). In view of the historic and ongoing boat traffic between Stewart Island, Big South Cape Island, and New Zealand's South Island, it is surprising in our study to find a stark division of mtDNA haplotypes over a small spatial scale, enduring in time. The existence of this segregation supports several conclusions about the invasion pathway for Big South Cape Island and the history of ship rat colonisation of New Zealand.
Excluding Big South Cape Island, the haplotypes we identified clearly grouped as either southern South Island or Stewart Island. Given the differences between these two haplotype clusters, compared to relative uniformity within them, and the relatively short time that ship rats have been in New Zealand (100 to 150 years over the course of our study), this clustering suggests that the original $19^{\text {th }}$ century ship rat colonisation of Stewart Island took place in a separate invasion event from that of the South Island.

The only ship rat haplotype ever detected on Big South Cape Island, in either historical or contemporary samples, is haplotype 1. Despite extensive sampling of Stewart Island and its other surrounding islands, we did not find any instances of haplotype 1 in these locations. We conclude that the hypothesis that rats swam from Stewart Island to Big South Cape Island is untenable.

The most likely explanation is that boats brought rats to Big South Cape Island. Wherever there are permanent moorings, rats can access boats and land easily, as they can run along the mooring lines. Three such moorings existed on the island at the time of the invasion (Bell 1978). Based on the differences in observed haplotypes our results indicate that the rats were not from anywhere on Stewart Island, including Port Pegasus which also serves as an anchorage for vessels operating in the region. In contrast, ship rat samples from islands on the east coast of Stewart Island, such as Tia, Joss and Pearl, all shared the same haplotype as those from Stewart Island. This further reinforces the belief that these islands are vulnerable to reinvasion by swimming (Russell et al. 2010), although transport of rats by boats to these islands from Stewart Island cannot be ruled out (Harper 2005).

The rats of Big South Cape Island are unlikely to have come from the ports at Bluff and Riverton at the southern tip of the South Island, regions apparently dominated by ship rats of haplotype 3 and 2 respectively. We are thus left with the hypothesis that the ship rats of Big South Cape Island came from outside the immediate region of Stewart Island and the south coast of the South Island. Our sampling indicates that the rats could have come from Fiordland (e.g. Doubtful Sound) or from the Port Chalmers region, which are both regions with active marine vessels that are likely to have visited Big South Cape Island during the time of the invasion. However, it remains impossible to be sure the rats of Big South Cape Island came from either of these specific locations, because haplotype 1 has a national and worldwide distribution and any visiting boat, large or small, could have been responsible for the incursion. There is also the added complication that, although boats could have come to Big South Cape Island via 
nearby ports in Stewart Island or southern New Zealand, their rats could have been picked up much further afield.

The genetic population structure of rats on Big South Cape Island, and putative source populations, may have changed considerably over the 50 years of our study. With the diversity of observed haplotypes in the region, and ongoing incursions of rats (e.g. Masuda \& Jamieson 2013), additional invasions may have resulted in genetic admixture, or in situ mutations may even be possible. Our use of historical museum specimens sampled at the time of the invasion gives us additional confidence in our conclusions. These samples showed no change in the predominant haplotypes of Big South Cape Island and Stewart Island over 50 years. However, our historical sampling did reveal a ship rat of mainland haplotype 2 sampled in December 1950 at Freshwater Hut on Stewart Island. Freshwater Hut is situated on a navigable river, with frequent boat traffic from other parts of Stewart Island and beyond. We suggest that this individual may represent an incursion to Stewart Island of a rat sourced from the South Island, although we cannot be sure in view of the geographical and temporal limitations of available samples. The enduring distinctiveness of the Stewart Island haplotype, despite the prevalence of boat traffic in the region, might be indicative of an incumbent effect whereby resident rats repel arrivals from distant locations (Fraser et al. 2015).

We can conclude that the rats of Big South Cape Island did not come from Stewart Island, or from the nearby ports of Bluff and Riverton. To determine with any more precision where the ship rats may have come from would require a more finely grained genetic study, perhaps using microsatellite markers. However, it is unlikely to be possible given the numbers of potential source populations and the time lapse since the invasion. Our results highlight the importance of rodent biosecurity at the highest levels, including even international ships visiting New Zealand (Russell et al. 2007).

\section{Acknowledgements}

This research was undertaken during the tenure of a Marsden Fast-start award UOA318 granted to RMF, and Bright Futures doctoral scholarships to SJM and JCR. GAH was employed by the Department of Conservation at the time of this research and his sampling work was funded by the Foundation for Research, Science \& Technology through a Post-Doctoral Fellowship (UOOX0232), a Public Good Research Fund Grant (RTIX0301), the Command Oil Damage Restoration Fund, through Oikonos (USA), the Ka Mate Nga Kiore Committee and the Zoology Department, Otago University. The Rakiura Tìtī Islands Committee and Rakiura Tìtī Island Administering Body provided permission and guidance through the research. Many thanks to the volunteers from the Rakiura mutton-birding community and elsewhere who assisted, and to the many island manu owners and in particular Ron Bull, who permitted access and often assistance. The sampling was carried out under the University of Otago Ethics approvals 102/02 and 85/04. Thanks to Sandy Bartle and Raymond Coory of Te Papa for assistance accessing museum specimens. We thank two anonymous reviewers for helpful comments on the manuscript.

\section{References}

Abdelkrim J, Pascal M, Calmet C, Samadi S 2005. Importance of assessing population genetic structure before eradication of invasive species: examples from insular Norway rat populations. Conservation Biology 19: 1-10.

Atkinson IAE 1973. Spread of the ship rat (Rattus r. rattus L.) in New Zealand. Journal of the Royal Society of New Zealand 3: 457-472.

Atkinson IAE 1985. The spread of commensal species of Rattus to oceanic islands and their effects on island avifaunas. In: Moors P ed Conservation of island birds: case studies for the management of threatened island species. Norwich, England, Paston Press. Pp. 35-81.

Bagasra A, Nathan H, Mitchell M, Russell JC 2016. Tracking invasive mammal dispersal with biomarker. New Zealand Journal of Ecology 40: 267-272.

Bandelt H, Forster P, Röhl A 1999. Median-joining networks for inferring intraspecific phylogenies. Molecular Biology and Evolution 16: 37-48.

Bell BD 1978. The Big South Cape Islands rat irruption. In: Dingwell PR, Atkinson IAE, Hay $\mathrm{C}$ eds The ecology and control of rodents in New Zealand Nature Reserves. Department of Lands and Survey Information Series No. 4. Pp. 33-45.

Bell EA, Bell BD, Merton D 2016. The legacy of Big South Cape: rat irruption to rat eradication. New Zealand Journal of Ecology 40: 212-218.

Colangelo P, Abiadh A, Aloise G, Amori G, Capizzi D, Vasa E, Annesi F, Castiglia R2015. Mitochondrial phylogeography of the black rat supports a single invasion of the western Mediterranean basin. Biological Invasions 17: 1859-1868.

Fewster RM, Miller SD, Ritchie J 2011. DNA profiling - a management tool for rat eradication. In: Veitch CR, Clout MN, Towns DR eds Island invasives: eradication and management. Gland, Switzerland, IUCN. Pp. 426-431.

Fraser CI, Banks SC, Waters JM 2015. Priority effects can lead to underestimation of dispersal and invasion potential. Biological Invasions 17: 1-8.

Harper GA 2005. Heavy rimu (Dacrydium cupressinum) mast seeding and rat (Rattus spp.) population eruptions on Stewart Island/Rakiura. New Zealand Journal of Zoology 32: $155-162$.

Harper GA, Rutherford M 2016. Home range and population density of black rats (Rattus rattus) on a seabird island: a case for a marine subsidised effect? New Zealand Journal of Ecology 40: 219-228.

Hingston M, Goodman SM, Ganzhorn JU, Sommer S 2005. Reconstruction of the colonization of southern Madagascar by introduced Rattus rattus. Journal of Biogeography 32: 1549-1559.

López M, Foronda P, Feliu C, Hernández M 2013. Genetic characterization of black rat (Rattus rattus) of the Canary Islands: origin and colonization. Biological Invasions 15: 2367-2372.

McClelland PJ, Coote R, Trow M, Hutchins P, Nevins HM, Adams J, Newman J, Moller H 2011. The Rakiura Tītī Islands Restoration Project: community action to eradicate Rattus rattus and Rattus exulans for ecological restoration and cultural wellbeing. In: Veitch CR, Clout MN, Towns DR eds Island invasives: eradication and management. Gland, Switzerland, IUCN. Pp. 451-454.

Masuda BM, Jamieson IG 2013. Response of a reintroduced bird population to a rat reinvasion and eradication. New 
Zealand Journal of Ecology 37: 224-231.

Miller SD 2008. Stochastic modelling of rat invasions among islands in the New Zealand archipelago. PhD Thesis. Auckland, University of Auckland. 380 p.

Moors PJ 1985. Eradication campaigns against Rattus norvegicus on the Noises Islands, New Zealand, using brodifacoum and 1080. In: Moors PJ ed Conservation of island birds. Cambridge, International Council for Bird Preservation Technical Publication No. 3. Pp. 153-155.

Nilsson MA, Härlid A, Kullberg M, Janke A 2010. The impact of fossil calibrations, codon positions and relaxed clocks on the divergence time estimates of the native Australian rodents (Conilurini). Gene 455: 22-31.

Robertson BC, Gemmell NJ 2004. Defining eradication units: introduced brown rats Rattus norvegicus on South Georgia, Southern Ocean. Journal of Applied Ecology 41: 1042-1048.

Robins JH, Hingston M, Matisoo-Smith E, Ross HA 2007. Identifying Rattus species using mitochondrial DNA. Molecular Ecology Notes 7: 717-729.

Russell JC, Clout MN 2005. Rodent incursions on New Zealand islands. In: Parkes J, Statham M, Edwards G eds Proceedings of the 13th Australasian Vertebrate Pest Conference. Lincoln, Landcare Research. Pp. 324-330.
Russell JC, Clout MN, Towns DR 2007. Early detection and eradication of invading rats. In: Witmer GW, Pitt WC, Fagerstone KA eds Managing Vertebrate Invasive Species: proceedings of an international symposium. Fort Collins, USDA/APHIS/WS, National Wildlife Research Center. Pp. 268-272.

Russell JC, Gleeson DM, Corre ML 2011. The origin of Rattus rattus on the Îles Éparses, Western Indian Ocean. Journal of Biogeography 38: 1834-1836.

Russell JC, Miller SD, Harper GA, MacInnes HE, Wylie MJ, Fewster RM 2010. Survivors or reinvaders? Using genetic assignment to identify invasive pests following eradication. Biological Invasions 12: 1747-1757.

Taylor RH, Thomas BW 1993. Rats eradicated from rugged Breaksea Island (170ha), Fiordland, New Zealand. Biological Conservation 65: 191-198.

Tollenaere C, Brouat C, Duplantier J-M, Rahalison L, Rahelinirina S, Pascal M, Moné H, Mouahid G, Leirs H, Cosson J-F 2010. Phylogeography of the introduced species Rattus rattus in the western Indian Ocean, with special emphasis on the colonization history of Madagascar. Journal of Biogeography 37: 398-410. 